\title{
Extent, Distribution, and Causes of Soil Acidity under Subsistence Farming System and Lime Recommendation: The Case in Wolaita, Southern Ethiopia
}

\author{
Fanuel Laekemariam (iD) ${ }^{1}$ and Kibebew Kibret ${ }^{2}$ \\ ${ }^{1}$ Wolaita Sodo University, Department of Plant Science, P.O. Box 138, Wolaita Sodo, Ethiopia \\ ${ }^{2}$ Haramaya University, School of Natural Resources Management and Environmental Sciences, P.O. Box 138, \\ Dire Dawa, Ethiopia \\ Correspondence should be addressed to Fanuel Laekemariam; laeke2005@yahoo.com
}

Received 27 February 2021; Revised 23 July 2021; Accepted 2 September 2021; Published 26 September 2021

Academic Editor: Durgesh Jaiswal

Copyright (c) 2021 Fanuel Laekemariam and Kibebew Kibret. This is an open access article distributed under the Creative Commons Attribution License, which permits unrestricted use, distribution, and reproduction in any medium, provided the original work is properly cited.

\begin{abstract}
Soil acidity is one of the most important environmental threats to the Ethiopian highlands where the livelihood of the majority of people is reliant on agriculture. Yet, information regarding its extent, distribution, causes, and lime requirement at a scale relevant to subsistence farming systems is still lacking. This study (1) investigates the extent and spatial distribution of soil acidity, (2) identifies factors attributing to soil acidification, and (3) predicts the lime requirement for major crops. A total of 789 soil samples were collected from arable lands in the Wolaita area which is mainly characterized by poor soil fertility and soil degradation in southern Ethiopia. Results revealed that the landscape is characterized by a gentle slope followed by strongly sloppy $>$ flat $>$ hilly topographies. Clay is the dominant soil textural class. A soil $\mathrm{pH}$ map, which is generated using geospatial analysis, demonstrates that $3.3,78.0$, and $18.7 \%$ of the total area were under strongly acidic, moderately acidic, and neutral soil reactions, respectively. The exchangeable acidity $(\mathrm{Cmol}(+) / \mathrm{kg})$ varied from nil to 5.1 , whereas exchangeable $\mathrm{Al}$ ranged from 1.4 to $19.9 \mathrm{Cmol}(+) / \mathrm{kg}$. The soil $\mathrm{pH}$ has shown a significantly $(p<0.001)$ negative association with clay content $(r=-0.33)$, exchangeable $\mathrm{Al}(r=-61)$, exchangeable acidity $(r=-0.58)$, and inorganic fertilizer application $(r=-0.33)$. Increased rates of diammonium phosphate (DAP) $\left(r^{2}=0.91\right)$ and urea $\left(r^{2}=0.88\right)$ markedly elevated soil acidity. Conversely, manuring showed a significant $(p<0.001)$ and positive relationship with $\mathrm{pH}(r=0.37)$ in which the increasing rate of manure significantly reduced acidification $\left(r^{2}=0.98\right)$. DAP and urea applications above $75 \mathrm{~kg} /$ ha lowered soil $\mathrm{pH}$ units by 0.56 and 0.48 , respectively, $<25 \mathrm{~kg} / \mathrm{ha}$ while at the same time farmyard manure (FYM) at $4 \mathrm{t} / \mathrm{ha}$ raised $\mathrm{pH}$ by 0.75 units over the unfertilized field. Residue management significantly $(p<0.001)$ influenced soil $\mathrm{pH}$ wherein it ranged from 6.09 (complete residue removal) to 6.61 (residue incorporation). Changes in land use, cropping intensity, and socioeconomic status were also significantly attributed to soil acidification. To curb the effects of soil acidity, the lime requirement for common bean growing fields varied from zero to $6.6 \mathrm{t} / \mathrm{ha}$, while for maize it was between zero and $4.3 \mathrm{t} / \mathrm{ha}$. It is concluded that soil management interventions such as maintaining and incorporating crop residues, integrated use of organic and inorganic fertilizers, liming, and enhancing farmers' awareness should be advocated to overcome soil acidification and improve soil fertility. In addition, introducing crops with traits that tolerate acidity and Al toxicity is also suggested.
\end{abstract}

\section{Introduction}

Crop plants need 17 kinds of nutrients to complete the life cycle, of that 14 nutrients should be present in the soil in adequate quantity and proportion for healthy plant growth [1]. However, the availability of nutrients is influenced by chemical reactions like acidity or alkalinity in the soil. Soil acidity and soil calcareousness are thought to be the two major crop production constraints considerably threatening the global food production system and afterward food security [2].

Agriculture plays the most important share in the Ethiopian economy, and therefore, the sector heavily depends on soil. About $43 \%$ of cultivated lands in Ethiopia, 
where major staple food crops are grown, are affected by soil acidity [3]. The realm might probably be larger because of the conversion of forest and grazing lands into arable lands as a result of fast human population increment and associated poor land management practices [4]. This signifies the magnitude of how soil acidification is threatening crop production and thus reducing food security particularly in the Ethiopian highlands where the area is conducive for soil acidification processes $[2,3]$.

Soil acidity resulted from a rise in the concentration of hydrogen ions $\left(\mathrm{H}^{+}\right)$. It should occur because of natural and human-induced processes. Acid parent materials, leaching of basic cations (calcium $\left(\mathrm{Ca}^{2+}\right)$, magnesium $\left(\mathrm{Mg}^{2+}\right)$, and potassium $\left(\mathrm{K}^{+}\right)$), hydrolysis reactions within the soil exchange sites, rainfall containing sulphuric and nitric acids, cations uptake by the crop over the long run cultivation, crop residue removal, and addition of soluble salts and fertilizers into the soil (mineral and organic) would possibly cause soil acidification [3, 5-7]. In Ethiopia, though the amount of inorganic fertilizers applied was in small doses (e.g., $[8,9])$, repeated use of urea $(46 \mathrm{~N}-0-0)$ and diammonium phosphate (DAP) $\left(18 \mathrm{~N}-46 \mathrm{P}_{2} \mathrm{O}_{5}-0\right)$ over many years was reported as a favoring factor for soil acidification in the Northwestern and Southwestern highlands of Ethiopia [10, 11]. In general, soil acidity elevates aluminum $\left(\mathrm{Al}^{3+}\right)$ concentration within the soil solution to a level of toxicity [5], limits the availability of essential plant nutrients, and restricts crop performance [12]. This would imply that soil acidity and associated low nutrient availability are among the major constraints toward attaining sustainable production and achieving food security. Therefore, investigating soil acidity, mapping its extent, and planning applicable management techniques are fundamental to realize sustainable levels of agricultural production.

In Ethiopia, agricultural production is irresistible of subsistence nature. According to Gebissa [13], 97\% of Ethiopian agricultural activities are constituted by subsistence farmers. Subsistence farming is a form of farming in which nearly all of the crops or livestock raised are used to feed the family. Generally, land degradation including soil acidity is a great threat to future agricultural production in the country $[2,3,13]$. Varied soil management practices that farmers apply into their field like the use of inorganic or organic fertilizers $[5,14,15]$, returning of crop residue into the soil [3], and the practice of continues cropping over mono-cropping or crop rotation 16, 10 influence soil acidity. Meanwhile, liming is the most widely used technique to correct soil acidity, cut back phytotoxic levels of $\mathrm{Al}$ and $\mathrm{Mn}$, and lift soil $\mathrm{pH}$ to the amount that is appropriate for maximum nutrient availability, plant growth, and crop yield $[12,15]$. Yet, the amount of lime to mitigate soil acidity depends on the acid tolerance level of the crop [10, 17], level of soil $\mathrm{pH}$, soil and the lime type, and the farming method [18]. However, empirical evidence on soil acidity and attributing factors and also the lime needed to reclaim acidity for subsistence farming system is lacking. Therefore, this study (1) assesses the extent and spatial distribution of soil acidity, (2) identifies the factors attributing to soil acidification, and (3) suggests the lime needed for reclamation of soil acidity.

\section{Materials and Methods}

2.1. Study Area. The study was conducted in three districts of the Wolaita zone in Southern Ethiopia. The districts (Damot Gale, Damot Sore, and Sodo Zuria) cover 84,000 hectares (ha) of land located between $037^{\circ} 35^{\prime} 30^{\prime \prime}-037^{\circ} 58^{\prime} 36^{\prime \prime} \mathrm{E}$ and $06^{\circ} 57^{\prime} 20^{\prime \prime}-07^{\circ} 04^{\prime} 31^{\prime \prime} \mathrm{N}$. The ten-year mean annual rainfall and temperature were $1355 \mathrm{~mm}$ and $19.7^{\circ} \mathrm{C}$, respectively. The elevation ranges from 1473 to 2873 meter above sea level (m.a.s.l). The predominant soils are Nitisols [19]. Generally, the soil has an acidic reaction with varying degrees [16].

Rain-fed-based agriculture is the major source of livelihood. The major grain crops include tef (Eragrostis tef (Zucc.) Trotter), maize (Zea mays L.), bread wheat (Triticum aestivum L.), haricot bean (Phaseolus vulgaris L.), and field pea (Pisum sativum L.). The root and tuber crops such as sweet potato (Ipomoea batatas), taro (Colocasia esculenta), potato (Solanum tuberosum), and enset (Ensete ventricosum) are also widely cultivated. The surroundings of homestead areas are used for perennial crops. Continuous cultivation without fallowing is common in the area. Farmers commonly apply organic fertilizer sources for perennial crops while they used inorganic fertilizers for annual crops. The inorganic fertilizers used at the time of study include urea (46N-0-0) and diammonium phosphate (DAP) $\left(18 \mathrm{~N}-46 \mathrm{P}_{2} \mathrm{O}_{5}-0\right)$.

\subsection{Soil Sampling and Laboratory Analysis}

2.2.1. Soil Sampling and Preparation Procedure. From the three districts, 789 surface soil samples were collected, airdried, ground, and sieved through a $2 \mathrm{~mm}$ mesh. The sampling points were geo-referenced using geographical positioning system (GPS) (model Garmin GPSMAP 60Cx). The depth of sampling for grain crops was $0-20 \mathrm{~cm}$ while for perennial crops it extended up to $50 \mathrm{~cm}$. Depending on topography and observed heterogeneity, 10 to 15 subsamples were taken to form a kilogram of the composite sample.

2.2.2. Soil Analysis. Soil samples were analyzed for $\mathrm{pH}$, exchangeable acidity (EA), exchangeable Al, exchangeable bases ( $\mathrm{Ca}, \mathrm{Mg}, \mathrm{K}$, and $\mathrm{Na}$ ), and effective cation exchange capacity (ECEC). Soil $\mathrm{pH}$ was measured using a $\mathrm{pH}$ meter with a ratio of $1: 2.5$ soil to water [20]. The EA was determined by leaching with potassium chloride $(\mathrm{KCl})$ followed by titrating with $0.02 \mathrm{M} \mathrm{HCl} \mathrm{[21].} \mathrm{Exchangeable} \mathrm{bases}$ and $\mathrm{Al}$ were determined using the Mehlich-3 method [22], and the concentration of elements was measured using an inductively coupled plasma (ICP) spectrometer. Then, ECEC was computed as a summation of exchangeable bases (Ca, $\mathrm{Mg}, \mathrm{K}$, and $\mathrm{Na}$ ) plus EA.

2.3. Estimation of Lime Requirement (LR). Haricot bean, wheat, and maize are major field crops grown in the study area. The crops have different acid tolerance levels and were purposively selected for lime requirement (LR) estimation. Their LR was estimated based on Taye [17] as 


$$
\mathrm{LR}=1600(\mathrm{EA}-(\mathrm{ECEC} * \mathrm{PAS})),
$$

where LR is the lime rate (ton/ha), EA is the exchangeable acidity ( $\mathrm{cmolc} \mathrm{kg}^{-1}$ ), ECEC is the effective cation exchange capacity $\left(\mathrm{cmolc} \mathrm{kg}^{-1}\right)$, and PAS is the permissible acid saturation for a specific type of crop (\%).

Crop tolerance level indicates the PAS that can be tolerated by different crops [6]. The PAS used to calculate the lime requirement for major crops grown in Ethiopia was 5\% for beans, $10 \%$ for most annual crops (e.g., wheat and barley), and $20 \%$ for maize $[10,17]$.

2.4. Digital Mapping of Soil Acidity and LR. Point data of soil $\mathrm{pH}, \mathrm{EA}$, and LR were interpolated for unsampled locations using Ordinary Kriging. The semivariogram is represented in equation (24) [23].

$$
\gamma(h)=\frac{1}{2 n} \sum_{n=1}^{n}\left[Z\left(X_{i}\right)-Z\left(X_{i}+h\right)\right]^{2},
$$

where $n$ is the number of pairs of sample points separated by the distance $h$ and $Z\left(x_{i}\right)$ 's are the value of the characteristic under study at $i^{\text {th }}$ location $(i=1,2,3, \ldots, n)$.

2.5. Statistical Data Analysis. The data were subjected to analysis of variance (ANOVA) with a one-way approach using Statistix software version 8.0. Whenever significant differences $(p<0.05)$ were detected, Tukey's HSD (Tukey's Honestly Significant Difference) test was performed to compare means. Furthermore, the data were evaluated using descriptive statistics and Pearson's correlation analysis. The values of the coefficient of variation (CV) of soil properties were rated as low $(<20 \%)$, moderate $(20-50 \%)$, and highly variable (>50\%) [24]. Geospatial analysis, mapping, and lime requirements were executed using GIS software (Arc Map version 10.4.1).

\section{Results and Discussion}

3.1. Extent and Distribution of Soil Acidity. Soil $\mathrm{pH}$ was between 4.5 and 8.0 with a mean $\mathrm{pH}$ value of $6.13 \pm 0.39$ (Table 1) [25]. It showed low variability $(\mathrm{CV}<20 \%)$. From the total sample size, $21 \%$ were strongly acidic $(\mathrm{pH}<5.5)$, $53.3 \%$ moderately acidic (5.6-6.5), $22.7 \%$ neutral (6.6-7.3), and $3.06 \%$ moderately alkaline (7.4-8.4) [25]. The exchangeable acidity $(\mathrm{Cmol}(+) / \mathrm{kg})$ based on the sample observation ranges from nil to 5.1 whereas exchangeable $\mathrm{Al}$ varied from 1.4 to 19.9 with a mean value of $9.02 \mathrm{Cmol}$ $(+) / \mathrm{kg}$ (Table 1). Based on geospatial analysis, 3.3, 78, and $18.7 \%$ of the total area were qualified under strongly acidic $(<5.5)$, moderately acidic (5.6-6.5), and neutral (6.6-7.3), respectively (Figure 1 [25]; Figure 1(a)). Soil pH exhibited a significantly $(p \leq 0.001)$ negative correlation with exchangeable acidity $(r=-0.58)$ and exchangeable $\mathrm{Al}$ $(r=-0.67)$ (Table 2).

Crops have different abilities to tolerate acid soil conditions [3]. Nonetheless, crop production is restrained at $\mathrm{pH}$ values below 5.5-6.5 [26]. Consequently, the observed values of soil $\mathrm{pH}$, exchangeable acidity, and exchangeable $\mathrm{Al}$ could demonstrate the presence of certain influences on nutrient availability [16] and crop productivity [3].

\subsection{Factors in Relation to Soil Acidification}

3.2.1. Landscape Characteristics and Soil Texture. Landscape, which is characterized by topographic position, elevation, slope, and aspect, did not show a significant influence on the soil $\mathrm{pH}$ (Table 3). However, a declining trend in soil $\mathrm{pH}$ from flat toward hilly topographic position was recorded. Elevation in the study area ranges between 1473 and 2873 m.a.s.l where the area is predominantly characterized by mid-highland (1500-2300 masl) agroecology [9]. Thus, its influence on microclimate and then soil reaction may be limited. The slope is related to soil erosion and deposition processes. Yet, the majority (68\%) of the study area is within flat to gentle slope conditions, and hence, significant variation in soil $\mathrm{pH}$ was less recorded. The finding agrees with Melku et al. [27] who reported a statistically nonsignificant difference in soil $\mathrm{pH}$ between slope classes and landscape positions in Geshy subcatchment, Gojeb River Catchment, Ethiopia. The authors mentioned decreasing trend of soil $\mathrm{pH}$ with increasing slope classes. Aspect is related to the amount of solar energy received by the slope and affects plant growth and soil water content [28]. The area is predominantly characterized by flat-gentle topography, and its influence on soil $\mathrm{pH}$ was not found statistically significant $(p>0.05)$ (Table 3$)$.

Soil texture significantly $(p<0.001)$ influenced soil $\mathrm{pH}$ (Table 3). The mean $\mathrm{pH}$ value ranged from 5.99 in clayey soils to 6.46 in silt loam soils (Table 3). Clay particles are the most active portions determining the soil's chemical activity. The reason for the lower soil $\mathrm{pH}$ could be attributed to the influences of higher clay content on active, exchangeable, and reserve acidity. This is also supported by a significant $(p<0.001)$ and negative relationship between soil $\mathrm{pH}$ with clay content $(r=-0.33)$, exchangeable $\mathrm{Al}(r=-61)$, and exchangeable acidity $(r=-0.59)$. In agreement, Chalsissa et al. [10] reported lower soil $\mathrm{pH}$ on clay soils due to a relatively higher concentration of exchangeable acidity. The authors also associated the lower $\mathrm{pH}$ with low soil OM content.

3.2.2. Soil Management Practices. Application of inorganic fertilizers containing nitrogen $(\mathrm{N})$ and phosphorus $(\mathrm{P})$ in the form of urea (46N-0-) and diammonium phosphate (DAP) $\left(18 \mathrm{~N}-46 \mathrm{P}_{2} \mathrm{O}_{5}-0\right)$ application has long been started 50 years ago in Ethiopia. Fields continuously managed with inorganic fertilizer showed significantly $(p<0.001)$ lower soil $\mathrm{pH}$ than unfertilized fields (Table 4). Generally, the amount of inorganic fertilizers applied to soil was less than the blanket dose [9]. Yet, $\mathrm{pH}$ decline was recorded at the increasing rate of DAP and urea fertilizers (Tables 2 and 4, Figures 2 and 3 ). On average, application of DAP and urea above $75 \mathrm{~kg} / \mathrm{ha}$ decreased $\mathrm{pH}$ by 0.56 and 0.48 units, respectively, compared to applications below $25 \mathrm{~kg} / \mathrm{ha}$. Similarly, research reports from western Ethiopia [10] and northwestern Ethiopia [11] indicated that the application of DAP and urea fertilizers in 
TABLE 1: Descriptive statistics of predicted values of soil properties for maps using geostatistical analysis (point sample $=789$ ).

\begin{tabular}{|c|c|c|c|c|c|c|}
\hline Soil properties & Unit & Mean & $\mathrm{SD}$ & Min & Max & $\mathrm{CV}(\%)$ \\
\hline$\overline{\mathrm{pH}}$ _ point observation & & 6.11 & 0.63 & 4.5 & 8.0 & 10.4 \\
\hline $\mathrm{pH}_{-}$after mapping & - & 6.13 & 0.39 & 5.02 & 7.28 & 6.0 \\
\hline Ex. Al_point observation & $\mathrm{Cmol}(+) / \mathrm{kg}$ & 9.02 & 2.01 & 1.4 & 19.9 & 22.4 \\
\hline Ex. Acidity_point observation & $\mathrm{Cmol}(+) / \mathrm{kg}$ & 0.32 & 0.83 & 0.00 & 5.12 & 257 \\
\hline
\end{tabular}

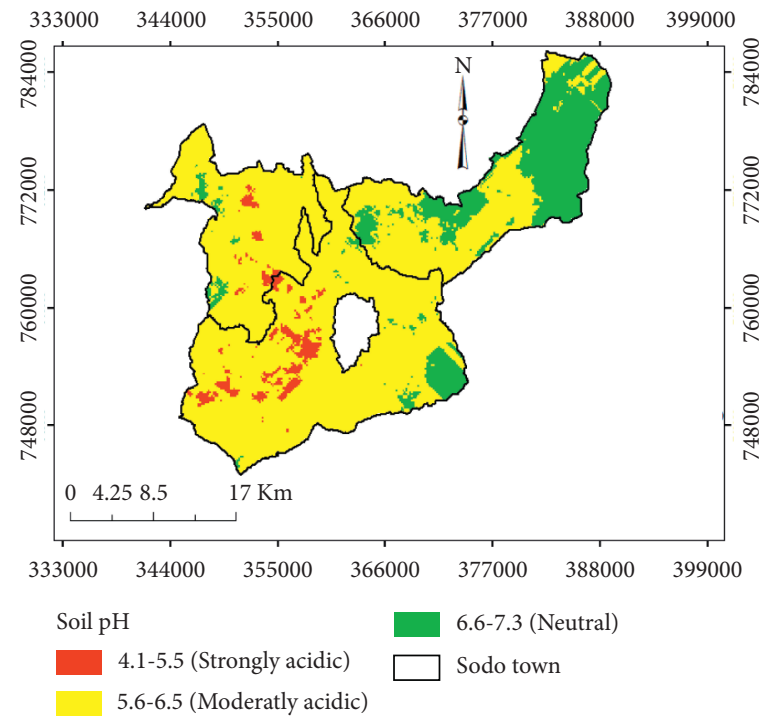

(a)

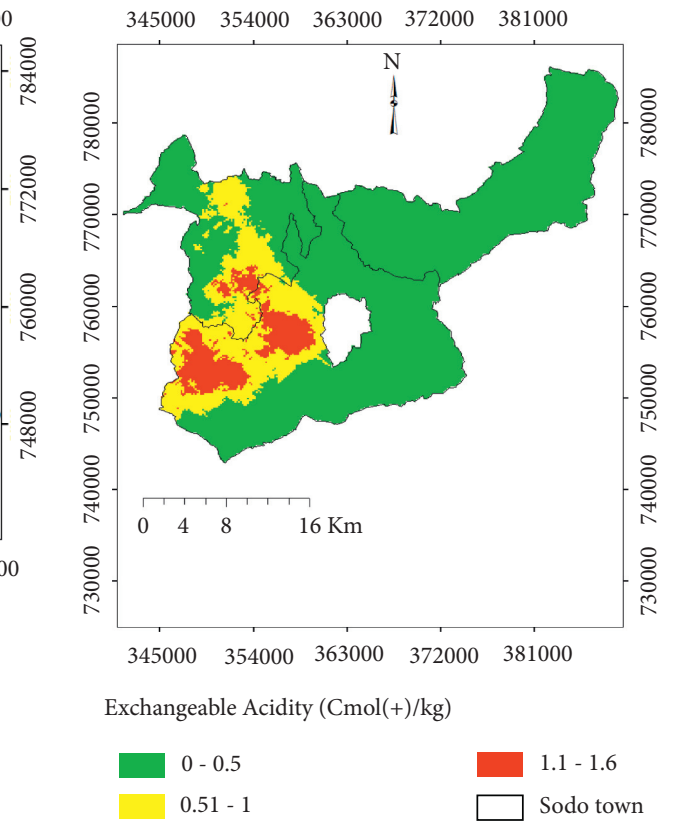

(b)

Figure 1: (a) Extent and spatial distribution of soil pH across the study site. (b) Extent and spatial distribution of exchangeable acidity (Cmol $(+) / \mathrm{kg})$ across the study site.

TABle 2: Pearson's correlation matrix between soil $\mathrm{pH}$ and different factors in crop lands $(N=674)$.

\begin{tabular}{|c|c|c|c|c|c|c|c|c|}
\hline & $\mathrm{pH}$ & Altitude (m.a.s.l) & Slope (\%) & CI no. & $\mathrm{Al} \mathrm{Cmol}(+)(\mathrm{kg})$ & Ex. Ac Cmol (+) (kg) & FYM $t$ (ha) & DAP $(\mathrm{kg} / \mathrm{ha})$ \\
\hline Altitude & $0.03^{\mathrm{ns}}$ & & & & & & & \\
\hline Slope & $0.00^{\mathrm{ns}}$ & $0.49^{* *}$ & & & & & & \\
\hline Crop intensity (CI) & $-0.16^{* *}$ & $-0.02^{\mathrm{ns}}$ & $-0.13^{* *}$ & & & & & \\
\hline $\mathrm{Al}$ & $-0.67^{* *}$ & $0.05^{\mathrm{ns}}$ & $0.15^{* *}$ & $0.08^{*}$ & & & & \\
\hline Ex. Ac & $-0.58^{* *}$ & $-0.10^{*}$ & $-0.06^{\mathrm{ns}}$ & $0.05^{\mathrm{ns}}$ & $0.63^{* *}$ & & & \\
\hline FYM & $0.37^{* *}$ & $0.03^{\mathrm{ns}}$ & $-0.05^{\mathrm{ns}}$ & $-0.23^{* *}$ & $-0.25^{* *}$ & $-0.15^{* *}$ & & \\
\hline DAP & $-0.39^{* *}$ & $-0.14^{* *}$ & -0.05 & $0.14^{* *}$ & $0.20^{* *}$ & $0.20^{* *}$ & $-0.46^{* *}$ & \\
\hline Urea & $-0.10^{*}$ & $-0.14^{* *}$ & $-0.06^{\mathrm{ns}}$ & $-0.06^{\mathrm{ns}}$ & $-0.01^{\mathrm{ns}}$ & $0.01^{\mathrm{ns}}$ & $-0.17^{* *}$ & $0.42^{* *}$ \\
\hline
\end{tabular}

$\mathrm{CI}=$ cropping intensity, $\mathrm{Al}=$ aluminum, Ex.Ac $=$ exchangeable acidity, $\mathrm{FYM}=$ farmyard manure, $\mathrm{DAP}=$ Diammonium phosphate, ns $=$ not significant, ${ }^{*} p<0.05,{ }^{* *} p<0.01$.

TABLe 3: Effects of topographic position and soil texture on the mean value of soil $\mathrm{pH}(n=789)$.

\begin{tabular}{lccc}
\hline Topographic position and slope & $\mathrm{pH}$ & Textural class & $\mathrm{pH}$ \\
\hline $\mathrm{F}(<4 \%)$ & $6.13(157)$ & Silt loam & $6.46 \mathrm{a}(148)$ \\
$\mathrm{GS}(4-8 \%)$ & $6.11(382)$ & Silt clay & $6.14 \mathrm{~b}(98)$ \\
SL $(8-16 \%)$ & $6.09(162)$ & Clay & $5.99 \mathrm{c}(543)$ \\
HI $(>16 \%)$ & $6.08(88)$ & $p$ value & $* * *$ \\
$p$ value & $\mathrm{NS}$ & - & \\
CV $(\%)$ & 10.4 & $\mathrm{CV}(\%)$ & 9.92 \\
\hline
\end{tabular}

$F=$ flat, GS = gentle slope, $\mathrm{SL}=$ strongly sloppy, $\mathrm{HI}=$ hilly. Note. Numbers in the bracket refer to sample size. ${ }^{* * *} p<0.001$. Means in a column followed by the same letters are not significantly different at $5 \%$ level of significance; $C V=$ coefficient of variation, NS = not significant. 
TABLE 4: Effects of fertilizer types and crop residue management on soil $\mathrm{pH}$.

\begin{tabular}{|c|c|c|c|c|c|}
\hline \multirow{2}{*}{ Field management } & \multicolumn{3}{|c|}{ Fertilizer types } & \multirow{2}{*}{ Crop residue status } & \multirow{2}{*}{$\mathrm{pH}$} \\
\hline & DAP & Urea & FYM & & \\
\hline Unfertilized & 6.24a (399) & $6.11(687)$ & $5.96 \mathrm{~b}(621)$ & Removed & $6.09 \mathrm{~b}(758)$ \\
\hline Fertilized & $5.97 \mathrm{~b}(390)$ & $6.06(102)$ & $6.66 a(168)$ & Maintained & $6.61 \mathrm{a}(31)$ \\
\hline$p$ value & $* * *$ & NS & $* * *$ & $p$ value & $* * *$ \\
\hline $\mathrm{CV}(\%)$ & 10.18 & 10.42 & 9.3 & $\mathrm{CV}(\%)$ & 10.3 \\
\hline
\end{tabular}

Note. Numbers in the bracket refer to sample size. ${ }^{* * *} p<0.001$. Means in a column followed by the same letters are not significantly different at $5 \%$ level of significance; $\mathrm{CV}=$ coefficient of variation; $\mathrm{NS}=$ not significant.

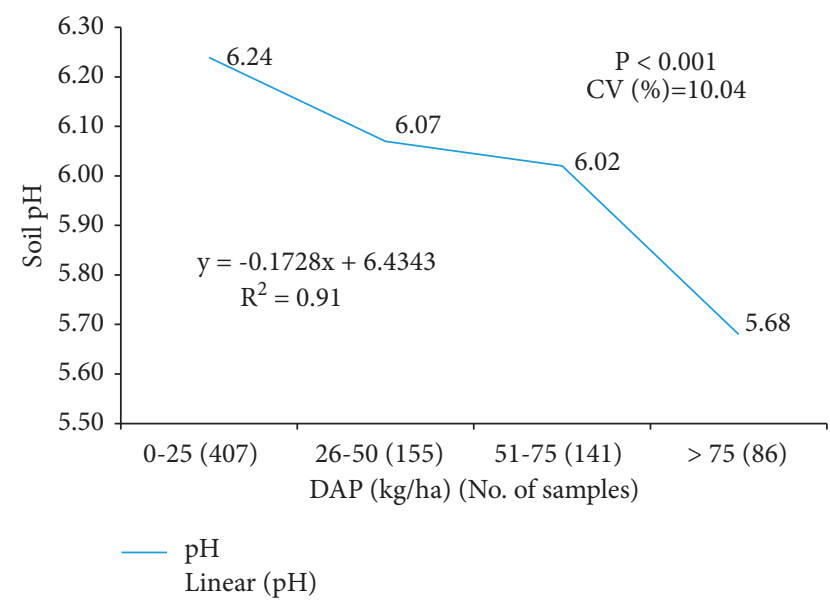

FIGURE 2: $\mathrm{pH}$ level on crop fields with different rates of DAP fertilizer.

cultivated fields resulted in soil acidification. Indeed, inorganic fertilizers have a considerable role in yield increment. Yet, in yield-making processes, plants uptake more cations than anions to neutralize organic acid synthesized, and consequently, more cations than anions are removed by crop with grain and residue [5]. This induces acidification especially when crop residues are removed from the cropland like the study area $[5,29]$. Additionally, ammonia-based fertilizers or other conditions that produce ammonia in the soil liberate more protons than the amount consumed during transformations processes within the soil and afterward generate acidification [5].

Alternatively, fields that have been continuously managed with farmyard manure (FYM) showed significantly $(p<0.001)$ higher soil $\mathrm{pH}$ than untreated fields (Tables 2 and 4 , Figure 4). The average $\mathrm{pH}$ unit increase due to farmyard manure application at $4 \mathrm{t} / \mathrm{ha}$ over the unfertilized field was 0.75 units (Figure 4). The result regarding the incorporation of crop residue also followed a similar pattern of FYM application (Table 4). This explains that the addition of organic fertilizers/retaining crop residue renders phytotoxic levels of $\mathrm{Al}$ by forming organo- $\mathrm{Al}$ complexes and increases the $\mathrm{pH}$ [3]. Manure application due to its high base cation concentrations alleviates acidification [14].

3.2.3. Land-Use Type, Cropping Intensity, and Continuous Cropping. Statistically significant differences in soil $\mathrm{pH}$ were recorded among land-use types (Table 5). The average $\mathrm{pH}$

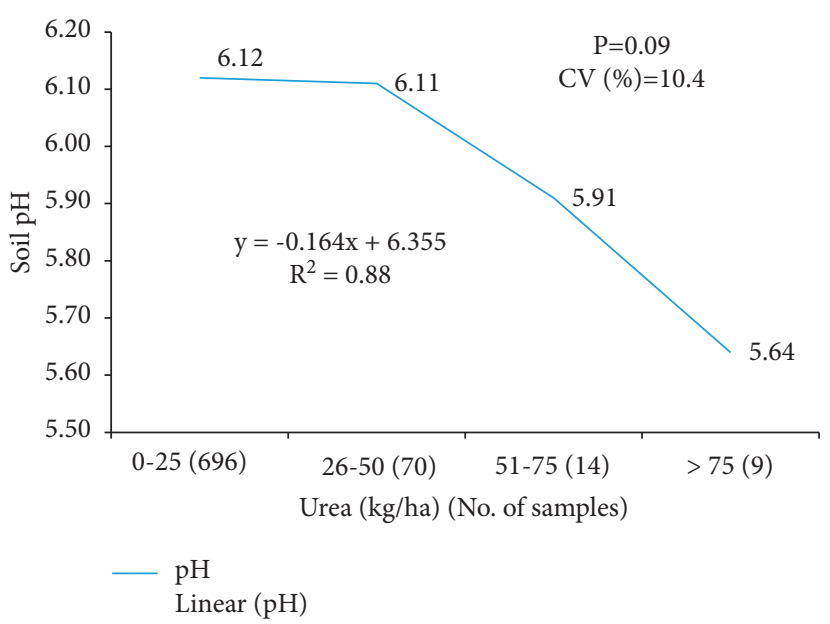

Figure 3: $\mathrm{pH}$ level on crop fields with different rates of urea fertilizer.

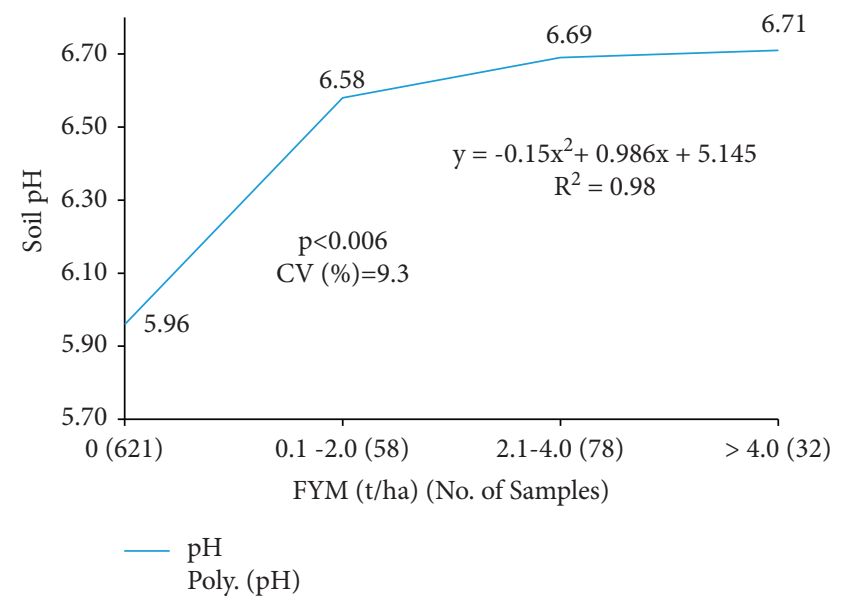

FIgURE 4: $\mathrm{pH}$ level on crop fields that received different rates of farmyard manure.

unit decline between the maximum (enset field) and the minimum (grassland) was 1.22 units followed by 0.91 units (main croplands) (Figure 5). The impact of land use on soil acidification depends on how it affects proton fluxes [5]. Comparing enset fields versus main field/grasslands, the latter is more acidified. This was because of variable management practices. Management practices, like organic fertilization, are common on enset fields than cereal and legume growing fields that were managed with inorganic fertilizers and rotation. Additionally, legumes grown as sole 
TABLE 5: Field position and cropping intensity effects on the mean value of soil $\mathrm{pH}(N=789)$.

\begin{tabular}{lccc}
\hline Field position & $\mathrm{pH}$ & Cropping intensity & $\mathrm{pH}$ \\
\hline$H$ & $6.77 \mathrm{a}(104)$ & One & $6.31 \mathrm{a}(254)$ \\
$M$ & $6.37 \mathrm{~b}(119)$ & Two & $6.06 \mathrm{~b}(395)$ \\
$D$ & $5.93 \mathrm{c}(566)$ & - & - \\
$p$ value & 0.0005 & $p$ value & 0.0001 \\
$\mathrm{CV}(\%)$ & 9.2 & $\mathrm{CV}(\%)$ & 10.3 \\
\hline
\end{tabular}

$H=$ homestead field, $M=$ middle field, $D=$ distant field; Note: numbers in the bracket refer to sample size. ${ }^{* * *} p<0.001$. Means in a column followed by the same letters are not significantly different at $5 \%$ level of significance; $\mathrm{CV}=$ coefficient of variation.

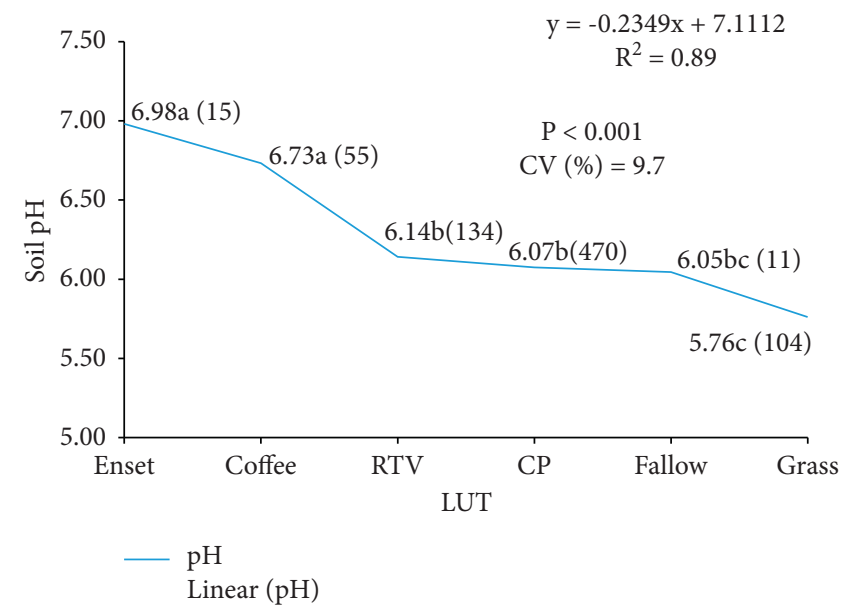

Figure 5: Soil pH along with different land-use types (note: numbers in the bracket refer to sample size). RTV = root, tuber, and vegetable crop field; $\mathrm{CP}=$ crop field.

and intercrop in the main field uptake excess cation to neutralize the carboxylic groups of amino acids during synthesis [5]. This together with the above-mentioned management practices might acidify main fields more than enset/coffee fields.

Cropping intensity refers to growing a number of crops in the same field continuously during one agriculture year. The result indicated that soil $\mathrm{pH}$ was significantly affected by cropping intensity (Table 5). Growing two successive crops in a year in the same field decreased soil $\mathrm{pH}$ more than monocropping did. Plants uptake more cations than anions to neutralize organic acid synthesized. It implies that the uptake would become more under continuous cultivation [9]. This may result in soil $\mathrm{pH}$ reduction. In agreement with this, Tesfaye et al. [30] reported $\mathrm{pH}$ decline under continuous cultivation. In the study area, farmers grow two successive crops by rotation. Cereals are often rotated with legumes and root crops [9]. According to Viera et al. [31], leguminous species increased soil acidification attributed to the increment in the removal of alkaline plant material by grain yield.

3.2.4. Farmers Perspective: Local Soil Types and Socioeconomic Status. Farmers in the study area have a tradition to classify soils and apply localized management accordingly. They used holistic approaches such as soil color,
TABLE 6: Soil pH level under farmers' soil types and on fields owned by farmers with different wealth statuses.

\begin{tabular}{lccc}
\hline Soil type & $\mathrm{pH}$ & Wealth & $\mathrm{pH}$ \\
\hline Arrada Bita & 6.45a (261) & Poor's_field & $6.25 \mathrm{a}(143)$ \\
Talla Bita & $6.24 \mathrm{~b}(94)$ & Medium_field & $6.11 \mathrm{~b}(423)$ \\
Kereta Bita & 6.17bc (27) & Rich_field & $6.06 \mathrm{~b}(161)$ \\
Lada Bita & $5.97 \mathrm{~cd}(149)$ & $p$ value & 0.0268 \\
Gobo Bita & $5.89 \mathrm{de}(118)$ & $\mathrm{CV}(\%)$ & 10.5 \\
Chere Bita & $5.76 \mathrm{ef}(48)$ & & \\
Zo’o Bita & $5.60 \mathrm{f} \mathrm{(92)}$ & & \\
$p$ value & 0.0006 & & 10.5 \\
CV (\%) & 9.2 & & \\
\hline
\end{tabular}

'Bita' literally means soil. Numbers in parenthesis indicate the sample size. Note: numbers in the bracket refer to sample size. ${ }^{* * *} p<0.001$. Means in a column followed by the same letters are not significantly different at $5 \%$ level of significance; $\mathrm{CV}=$ coefficient of variation.

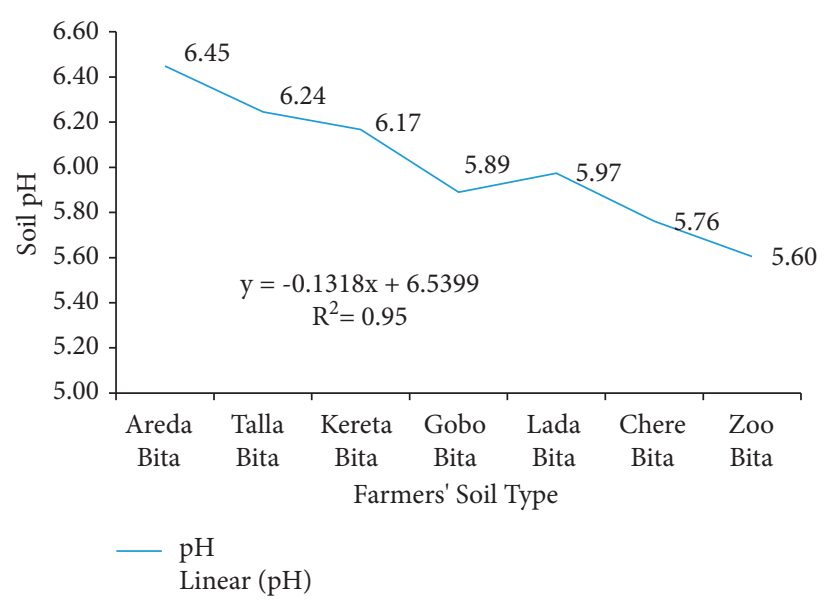

Figure 6: Soil pH along farmer's named soil types.

permeability, water retention capacity, workability, and soil fertility as assessed qualitatively. The details of perceived soil characteristics are found in Fanuel et al. [9]. Soil pH in view of farmers' soil nomenclature varied from 5.6 (Zo'o bita) to 6.4 (Arrada bita) (Table 6, Figure 6). Zo'o bita literally is red colored and nonfertile soil. Subsequently, farmers relatively apply higher amounts of inorganic fertilizer compared to Arrada bita (fertile soil) [9]. Zo'o bita has a higher clay fraction (71\%) than Arrada bita (45\%) and its $\mathrm{pH}$ declined significantly $p<0.001)$ with an increase of clay proportion $(r=-0.33)$.

In most cases, farmers apply home left wastes particularly wood ash and animal wastes into Arrada bita as it is mostly situated close to homestead. This might improve soil organic matter and base cations and finally end with higher $\mathrm{pH}$ compared to soils located on distant fields (e.g., Zo'o bita, Lada Bita, Chere Bita) which are mostly subjected to complete crop residue removal and inorganic fertilizer use. In agreement, Yihenew et al. [11] reported acidic soil reaction in cultivated fields due to depletion of basic cations through crop harvest and continuous use of urea and DAP $\left[\left(\mathrm{NH}_{4}\right)_{2} \mathrm{HPO}_{4}\right]$ fertilizers. In line with this, decreased soil $\mathrm{pH}$ from home fields to remote fields mostly due to differences 


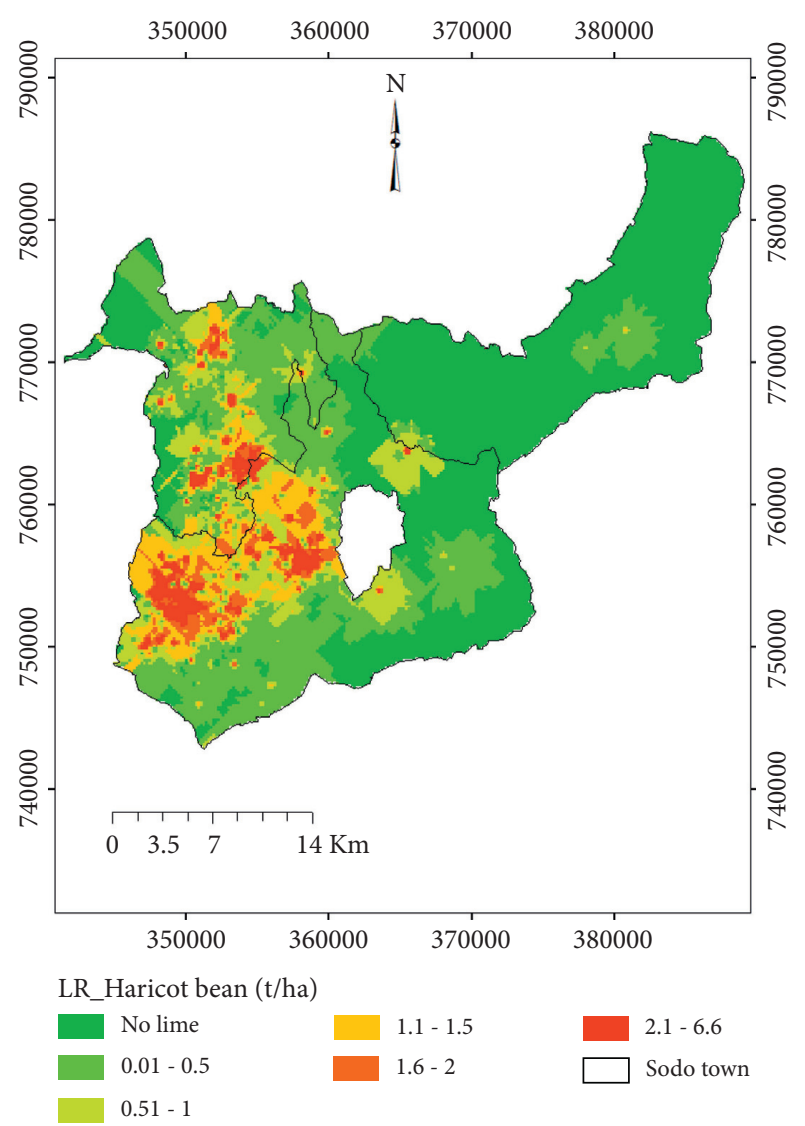

FIgURE 7: Extent and spatial distribution of lime requirement $(\mathrm{t} / \mathrm{ha})$ for legume (Haricot bean) production across the study site.

in input levels was reported by Chikowo et al. [32]. This finding implies that understanding farmers' soil typology could be useful for site-specific soil $\mathrm{pH}$ and nutrient management strategies.

Soil $\mathrm{pH}$ on the resource-poor farmers' field was significantly higher than the other wealthy groups (Table 6). Resource-poor farmers own less land than wealthy farmers and use a range of other sources of nutrients, such as compost, crop residues, and leaf litter compared to richer farmers who use mineral fertilizer [33]. The author also described that richer farmers produce more manure, mainly because they have larger herds. However, in terms of the amount being applied per unit of land, resource-poor farmers apply more manure per hectare because they only cultivate very small areas. This might have caused higher soil $\mathrm{pH}$ on resource-poor fields.

Despite the fact that poor farmers have little access to organic and inorganic nutrient sources, their land is being managed with better care to get more produce from it. On the contrary, wealthier farmers have a better land size and continuously cultivate under relatively higher application rates of inorganic fertilizer.

3.3. Estimating Lime Requirement. From the total area, 2,772 ha was strongly acidic $(<5.5)$ whereas 65,520 ha was moderately acidic (5.6-6.5) suggesting the need for sitespecific management in order to correct soil acidity. Liming



FIgURE 8: Extent and spatial distribution of lime requirement ( $t / h a)$ for maize production across the study site.

is widely considered a major option to manage soil acidity and sustaining food production. It is a quick and effective way to neutralize acidity, especially in highly acidic soils [29]. In addition, the growth of relatively acid-tolerant crop varieties on slightly acid soils is also suggested. The remaining 15,708 ha of the study area does not require lime.

The amount of lime estimated based on permissible acid saturation (PAS) level for the respective crops is presented in Figures 7-9. It was noted that lime requirement (LR) across landscapes varied depending on exchangeable acidity, exchangeable $\mathrm{Al}$, and soil $\mathrm{pH}$. This was substantiated by the highly significant correlation $\left(r=0.99,0.96,0.88^{* * *}\right)$ between exchangeable acidity and LR at 5\% PAS, 10\% PAS, and $20 \%$ PAS, respectively. The correlation between exchangeable $\mathrm{Al}$ and LR was also significantly positive at 5\% PAS $\left(r=0.62^{* *}\right), \quad 10 \%$ PAS $\left(r=0.59^{* * *}\right)$, and $20 \%$ PAS $\left(r=0.52^{* * *}\right)$. The correlation matrix for soil $\mathrm{pH}$ also showed a highly significant but negative relation with LR at 5\% PAS $\left(r=-0.54^{* * *}\right), 10 \%$ PAS $\left(r=-0.50^{* *}\right)$, and $20 \%$ PAS $\left(r=-0.43^{* *}\right)$. The strong spatial dependence of LR for semivariograms in all PAS computation also strengthens the earlier statements (Appendix Table 1).

It was estimated that the amount of lime required to neutralizing acidity on common bean fields varied from zero to $6.6 \mathrm{t}$ /ha (Figure 7 ), while for maize, it was between zero and $4.3 \mathrm{t}$ /ha (Figure 8 ). Farmers under strongly acidic soils, 


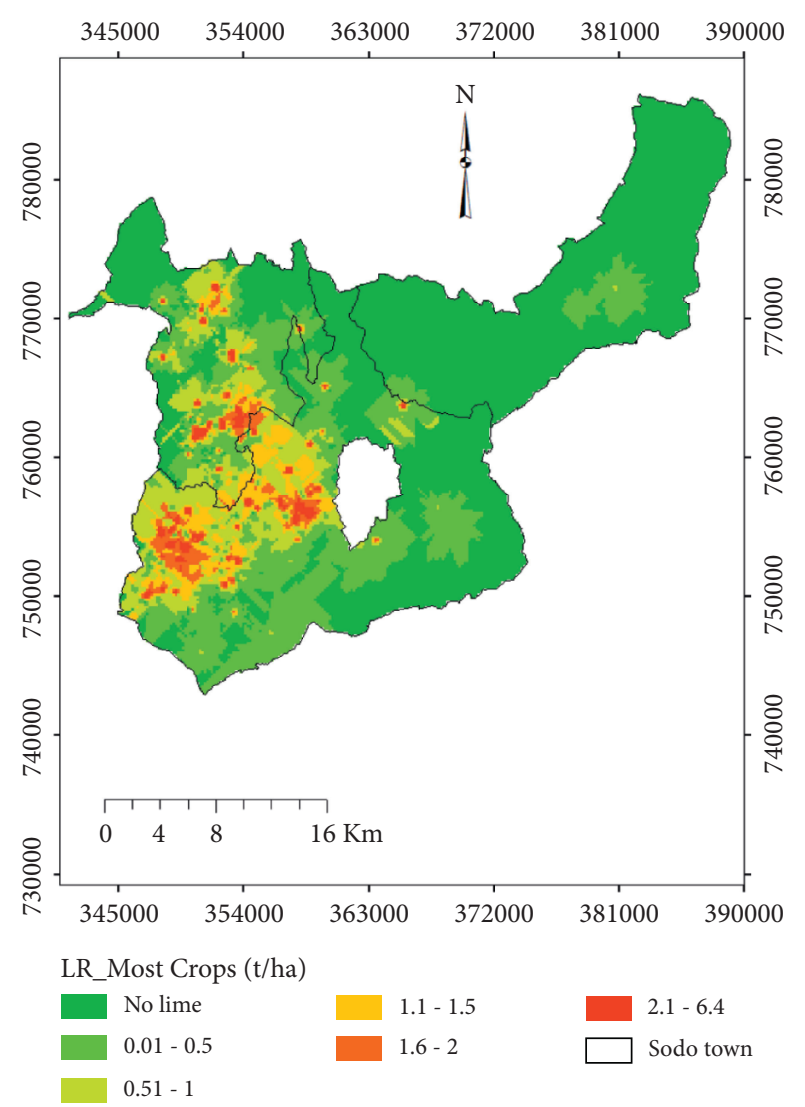

FIgURE 9: Extent and spatial distribution of lime requirement ( $\mathrm{t} / \mathrm{ha}$ ) for most annual crops production across the study site.

regardless of crop types, are advised to apply a maximum of $6.4 t$ lime/ha (Figure 9). Nevertheless, soil test-based adjustment prior to a lime application every year is also recommended. In addition, it should be stressed that liming cannot stand on its own to increase crop productivity; rather, it guarantees higher yield when used with an adequate and balanced supply of crop limiting nutrients. Nonetheless, liming may not be practical for resource-poor farmers due to supply shortages or high labor and monetary costs. Thus, integrating chemical fertilizer with manure and encouraging farmers to retain/incorporate residue to significantly alleviate soil acidification are relevant [29].

\section{Conclusion}

Soil acidity is identified as one of the most important constraints to crop production. However, the magnitude and extent of acidity are location-specific which suggests the need to have site-specific management. In the study area, where environmental and landscape characteristic systems are mostly similar, soil acidification is attributed to inherent and human-induced factors. Amount of clay, fertilizer type, land use, management practices, and socioeconomic conditions contributed to soil acidity. Liming is suggested as an effective way to counteract soil acidification and improve crop yields. Accordingly, the digital mapping indicated sitecrop-specific lime rates in which the amount varies based on the acid sensitivity of the crops. Smallholder farmers have to be encouraged to return crop residue and integrate chemical fertilizer with manure in order to reduce the impacts of soil acidity. In addition, introducing crops with traits that tolerate both acidity and $\mathrm{Al}$ toxicity is suggested. Finally, liming alone cannot be a complete solution to increase crop yield. Thus, it has to be integrated with an adequate and balanced supply of crop limiting nutrients.

\section{Data Availability}

The data used to support the findings of this study are available from the corresponding author upon request.

\section{Conflicts of Interest}

The authors declare that there are no conflicts of interest.

\section{Authors' Contributions}

All the authors collected, analyzed, interpreted, and prepared the manuscript.

\section{Acknowledgments}

The authors are grateful to the Ministry of Education (MOE) and now the Ministry of Science and Higher Education (MoSHE) and Ethiopian Soil Information System (EthioSIS) at the Agricultural Transformation Agency (ATA) for financial support.

\section{Supplementary Materials}

Appendix 1: model performance and semivariogram characteristics of soil properties of the study area. (Supplementary Materials)

\section{References}

[1] N. K. Fageria, M. P. B. Filho, A. Moreira, and C. M. Guimarães, "Foliar fertilization of crop plants," Journal of Plant Nutrition, vol. 32, no. 6, pp. 1044-1064, 2009.

[2] M. B. Hossain, M. H. R. Khan, S. Khanom, and S. A. Shahid Akhtar Hossain, "Amelioration of soil acidity by the application of maize straw ash in mixed soil," Dhaka University Journal of Biological Sciences, vol. 30, no. 2, pp. 207-219, 2021.

[3] G. Agegnehu, C. Yirga, and andT. Erkossa, "(EIAR). Addis ababa, Ethiopia," Soil Acidity Management, Ethiopian Institute of Agricultural Research, 2019.

[4] B. Gurmessa, Soil Acidity Challenges and the Significance of Liming and Organic Amendments in Tropical Agricultural Lands with Reference to Ethiopia, Environment, Development and Sustainability, Addis ababa, Ethiopia, 2020.

[5] R. Alvarez, A. Gimenez, F. Pagnanini et al., "Soil acidity in the Argentine Pampas: effects of land use and management," Soil and Tillage Research, vol. 196, Article ID 104434, 2020.

[6] B. Iticha and C. Takele, "Digital soil mapping for site-specific management of soils," Geoderma, vol. 351, pp. 85-91, 2019.

[7] J. L. Havlin, S. L. Tisdale, W. L. Nelson, and J. D. Beaton, Soil Fertility and Fertilizers: An Introduction to Nutrient Management, Pearson, Uper Sadle River: NJ, 2014. 
[8] E. Eyasu, P. F. Okoth, and E. M. A. Smaling, "Explaining bread wheat (Triticum aestivum) yield differences by soil properties and fertilizer rates in the highlands of Ethiopia," Geoderma, vol. 339, pp. 126-133, 2019.

[9] F. Laekemariam, K. Kibret, T. Mamo, and E. Karltun, "Physiographical characteristics of agricultural land and farmers' soil fertility management practice in Wolaita Zone, Southern Ethiopia," Environmental System Research, vol. 5, p. 24, 2016.

[10] C. Takele, B. Iticha, and G. Sori, "Index," The Anabasis of Cyrus, vol. 18, no. 5, pp. 275-281, 2018.

[11] Y. Gebreselassie, F. Anemut, and A. Solomon, "The effects of land use types, management practices and slope classes on selected soil physico-chemical properties in Zikre watershed, North-Western Ethiopia," Springer Open Journal, Environmental Systems Research, vol. 4, no. 3, pp. 1-7, 2015.

[12] N. K. Fageria and V. C. Baligar, "Chapter 7 Ameliorating Soil Acidity of Tropical Oxisols by Liming For Sustainable Crop Production," Advances in Agronomy, vol. 99, pp. 345-399, 2008.

[13] G. Y. Wendimu, "The challenges and prospects of Ethiopian Agriculture," Cogent Food and Agriculture, vol. 7, p. 1923619 , 2021.

[14] A. P. Martins, S. E. V. G. Andrade Costa, I. Anghinoni et al., "Soil acidification and basic cation use efficiency in an integrated no-till crop-livestock system under different grazing intensities," Agriculture, Ecosystems \& Environment, vol. 195, pp. 18-28, 2014.

[15] S. Getaneh and W. Kidanemariam, "Soil acidity and its managements: a review," International Journal of Advanced Research in Biological Sciences, vol. 8, no. 3, pp. 70-79, 2021.

[16] F. Laekemariam and K. Kibret, "Explaining soil fertility heterogeneity in smallholder farms of southern Ethiopia," Applied and Environmental Soil Science, 2020.

[17] T. Bekele, "Estimation of lime requirement," in Training Manual for Regional SoilTesting Laboratory Heads and TechniciansNational soil Testing Center, Ministry of Agriculture and Rural Development, Addis Ababa, Ethiopia, 2008.

[18] K. W. T. Goulding, "Soil acidification and the importance of liming agricultural soils with particular reference to the United Kingdom," Soil Use and Management, vol. 32, no. 3, pp. 390-399, 2016.

[19] B. Tesfaye, Understanding farmers: Explaining soil and water conservation in Konso, Wolaita, and Wollo, Ethiopia, $\mathrm{PhD}$ Thesis, Wageningen University and Research Center, Wageningen, The Netherlands, 2003.

[20] R. Mylavarapu, UF/IFAS Extension Soil Testing Laboratory (ESTL) Analytical Procedures and Training Manual, 2009.

[21] S. Sahlemedhin and B. Taye, "Procedures for soil and plant analysis," National Soil Research Center, Ethiopian Agricultural Research Organization, Addis Abeba, Ethiopia, Technical Paper 74, 2000.

[22] A. Mehlich, "Mehlich III soil test extractant: a modification of Mehlich II extractant," Communications in Soil Science and Plant Analysis, vol. 15, pp. 1409-1416, 1984.

[23] C. Costa, E. M. Papatheodorou, N. Monokrousos, and G. P. Stamou, "Spatial variability of soil organic C, inorganic $\mathrm{N}$ and extractable $\mathrm{P}$ in a Mediterranean grazed area," Land Degradation \& Development, vol. 26, no. 2, pp. 103-109, 2015.

[24] U. A. Amuyou, E. B. Eze, P. A. Essoka, J. Efiong, and O. O. Egbai, "Spatial variability of soil properties in the Obudu Mountain region of southeastern Nigeria," International Journal of Humanities and Social Science, vol. 3, no. 15, pp. 145-149, 2013.
[25] EthioSIS, Soil Fertility Status and Fertilizer Recommendation Atlas for Tigray Regional State, Ethiopia, EthioSIS, Addis ababa, Ethiopia, 2014.

[26] J. Holland, P. White, M. Glendining, K. Goulding, and S. McGrath, "Yield responses of arable crops to liming-An evaluation of relationships between yields and soil $\mathrm{pH}$ from a long-term liming experiment," European Journal of Agronomy, vol. 105, pp. 176-188, 2019.

[27] M. Dagnachew, A. Moges, and A. Kebede, "Effects of soil and water conservation measures on soil quality indicators: the case of Geshy subcatchment, Gojeb River catchment, Ethiopia," Applied and Environmental Soil Science, vol. 2020, Article ID 1868792, 16 pages, 2020.

[28] H. Zhu, Y. Zhao, F. Nan, Y. Duan, and R. Bi, "Relative influence of soil chemistry and topography on soil available micronutrients by structural equation modeling," Journal of Soil Science and Plant Nutrition, vol. 16, no. 4, 2016.

[29] Q. Zhu, X. Liu, T. Hao et al., "Cropland acidification increases risk of yield losses and food insecurity in China," Environmental Pollution, vol. 256, Article ID 113145, 2020.

[30] W. Tesfaye, K. Kibebew, B. Bobe, T. Melesse, and E. Teklu, "Long term effects of cultivation on physicochemical properties of soils at metahara sugar estate," American-eurasian Journal of Agricultural \& Environmental Sciences, vol. 18, no. 5, pp. 246-257, 2018.

[31] F. C. B. Viera, C. Bayer, J. Mielniczuk, J. Zanatta, and C. A. Bissari, "Long-term acidification of a Brazilian Acrisol as affected by no till cropping systems and nitrogen fertilizer," Australian Journal of Soil Research, vol. 46, pp. 17-26, 2008.

[32] R. Chikowo, S. Zingore, S. Snapp, and A. Johnston, "Farm typologies, soil fertility variability and nutrient management in smallholder farming in Sub-Saharan Africa," Nutrient Cycling in Agroecosystems, vol. 100, no. 1, pp. 1-18, 2014.

[33] E. Elias, "Soil enrichment and depletion in southern Ethiopia," in Nutrients on the Move-Soil Fertility Dynamics in African Farming Systems, T. Hilhorst and F. M. Muchena, Eds., pp. 65-82, International Institute for Environment and Development, London, 2000. 